\author{
Marquette University \\ e-Publications@Marquette
}

$12-2010$

\title{
Study on Intumescent Flame Retarded Polystyrene Composites with Improved Flame Retardancy
}

Hongdian Lu

Marquette University

Charles A. Wilkie

Marquette University, charles.wilkie@marquette.edu

Follow this and additional works at: https://epublications.marquette.edu/chem_fac

Part of the Chemistry Commons

\section{Recommended Citation}

Lu, Hongdian and Wilkie, Charles A., "Study on Intumescent Flame Retarded Polystyrene Composites with Improved Flame Retardancy" (2010). Chemistry Faculty Research and Publications. 34.

https://epublications.marquette.edu/chem_fac/34 


\title{
Study of Intumescent Flame Retarded Polystyrene Composites with Improved Flame Retardancy
}

\author{
Hongdian Lu \\ Department of Chemical and Materials Engineering, Hefei \\ University \\ Hefei, Anhui, 230022, PR China \\ Charles A. Wilkie \\ Department of Chemistry and Fire Retardant Research Facility, \\ Marquette University \\ Milwaukee, WI
}

\begin{abstract}
:
The flame retardancy and thermal stability of ammonium polyphosphate/tripentaerythritol (APP/TPE) intumescent flame retarded polystyrene composites (PS/IFR) combined with organically-modified layered inorganic materials (montmorillonite clay and zirconium phosphate), nanofiber (multiwall carbon nanotubs), nanoparticle $\left(\mathrm{Fe}_{2} \mathrm{O}_{3}\right)$ and nickel catalyst were evaluated by cone calorimetry, microscale combustion calorimetry (MCC) and thermogravimetric analysis (TGA). Cone calorimetry revealed that a small substitution of IFR by most of these fillers $(\leq 2 \%)$ imparted substantial improvement in flammability performance. The montmorillonite clay exhibited the highest efficiency in reducing the peak heat release rate of PS/IFR composite, while zirconium phosphate modified with $\mathrm{C}_{21} \mathrm{H}_{26} \mathrm{NClO}_{3} \mathrm{~S}$ exhibited a negative effect. The yield and thermal stability of the char obtained from TGA correlated well with the reduction in the peak heat release rate in the cone calorimeter. Since intumesence is a condensed-
\end{abstract}

Polymer Degradation and Stability, Vol. 95, No. 12 (December 2010): pg. 2388-2395. DOI. This article is (C) Elsevier and permission has been granted for this version to appear in e-Publications@Marquette. Elsevier does not grant permission for this article to be further copied/distributed or hosted elsewhere without the express permission from Elsevier. 
NOT THE PUBLISHED VERSION; this is the author's final, peer-reviewed manuscript. The published version may be accessed by following the link in the citation at the bottom of the page.

phase flame process, the MCC results showed features different from those obtained from the cone calorimeter.

Keywords: Polystyrene, Intumescent flame retardant, Cone calorimetry, Microscale combustion calorimetry.

\section{Introduction}

The fire protection of polymeric materials by intumescent flame retardants (IFR) is a typical condensed-phase flame retardant mechanism. The IFR system is commonly composed of a precursor of a carbonization catalyst, such as ammonium polyphosphate (APP), a carbonization agent, such as a polyol, and a blowing agent. By the sequence of esterification, carbonization, expansion and solidification, the intumescent char generated from the IFR will cover the underlying material to protect it from the heat or flame and slow the mass transfer [1] and [2]. Over the past decade, inorganic nanofillers (montmorillonite clay [3] and [4], carbon nanotubes, [5] zirconium phosphate [6]), metallic oxides [7], [8], [9] and [10] $\left(\mathrm{MoO}_{3}, \mathrm{Fe}_{2} \mathrm{O}_{3}\right.$, $\mathrm{TiO}_{2}, \mathrm{La}_{2} \mathrm{O}_{3}$ ) and catalysts [11] have been added to the IFR to improve its flame retardant efficiency and thermal stability. As expected, the synergistic or catalytic effect induced by the addition will modify the chemical and/or physical behavior of the char and impart superior flame retardancy to polymeric materials, compared to those containing IFR alone.

Cone calorimetry is the most used technique to evaluate the flammability performance of polymeric materials. By measuring the time to ignition $\left(t_{i g n}\right)$, mass loss rate $(M L R)$, total heat released $(T H R)$, and especially heat release rate (HRR), the flammability of the materials can be quantified. However, a hundred grams of material and a long time are required to obtain these parameters, which make it less efficient to screen new flame retardant systems. High throughput (HT) apparatus and methods have been developed for the formulation and flammability performance screening of multicomponent polymeric materials in the past decade. Led by the National Institute of Standards and Technology (NIST), apparatus such as the radiant Panel Apparatus and Rapid Cone Calorimetry have been developed to acquire the critical fire parameters [12], [13], [14] and [15]. Besides these, pyrolysis combustion flow calorimetry,

Polymer Degradation and Stability, Vol. 95, No. 12 (December 2010): pg. 2388-2395. DOI. This article is (C) Elsevier and permission has been granted for this version to appear in e-Publications@Marquette. Elsevier does not grant permission for this article to be further copied/distributed or hosted elsewhere without the express permission from Elsevier. 
also known as microscale combustion calorimetry (MCC), has been developing as a new tool to screen for flammability of polymeric materials [16], [17], [18] and [19]. The correlation between MCC and other evaluation methods, such as cone calorimetry, limiting oxygen index (LOI), and vertical burning tests, has been good in some cases. Although a wealth of information on material flammability can be obtained by MCC from just a few milligrams of specimen, it cannot yet predict the fire performance of materials which are influenced by physical effects such as swelling, dripping and barrier formation [20]. Recently, the Bourbigot group developed a small-size and low-cost HT method to optimize the heat barrier effect of intumescent coating used for protecting steel, which showed good correlation with the results obtained from conventional fire testing [21].

Although $\mathrm{HT}$ is a benefit in reducing testing time and sample size, the HT tools are quite expensive at present and are not in wide use. The commonly used thermogravimetric analyzer (TGA) has been used to complement the HT apparatus for predicting the $t_{\text {ign }}$ of polymeric materials $22 \mathrm{a}, 22 \mathrm{~b}$ and [22]. In the case of intumescent flame retardant polymeric materials, the physical and chemical properties of intumescent char play an important role in the flammability performance. Information on the yield and thermal stability of intumescent char can be obtained through TGA, which provides the possibility to predict the flammability performance for the fire safety researcher. In this paper, flammability performance of intumescent flame retardant polystyrene (PS) with several nanofillers, including nanoparticle $\left(\mathrm{Fe}_{2} \mathrm{O}_{3}\right)$, nanofiber (carbon nanotube), nanoplatelet (montmorillonite clay and zirconium phosphate) and nickel catalyst, are characterized. The aim was to study the flammability performance of PS/IFR composites and establish a relationship between fire parameters from cone calorimetry and properties of char (yield and thermal stability) from TGA.

\section{Experimental}

\subsection{Materials}

Polystyrene (PS, $M_{w}$ 192,000, melt index $6.00-9.00 \mathrm{~g} / 10 \mathrm{~min}$ $\left(200^{\circ} \mathrm{C} / 5.0 \mathrm{~kg}\right.$, ASTM D1238)) was purchased from Aldrich Chemical Co. The intumescent flame retardant system contained ammonium

Polymer Degradation and Stability, Vol. 95, No. 12 (December 2010): pg. 2388-2395. DOI. This article is (c) Elsevier and permission has been granted for this version to appear in e-Publications@Marquette. Elsevier does not grant permission for this article to be further copied/distributed or hosted elsewhere without the express permission from Elsevier. 
polyphosphate (APP, $n=1000-3000$, Phos-chek ${ }^{\circledR} \mathrm{P} / 30$, ICL Performance Products LP) and tripentaerythritol (TPE, Aldrich). The nanofillers and catalyst, organically-modified montmorillonite clay (OMT, Cloisite15A, cation is dimethyldihydrogenated tallow ammonium, Southern Clay Products), multiwall carbon nanotubes (MWNT, Nanocyl, S.A, Belgium), iron oxide nanopowder $\left(\mathrm{Fe}_{2} \mathrm{O}_{3}\right.$, $<50 \mathrm{~nm}$, Aldrich) and nickel catalyst ( $\mathrm{Ni}-\mathrm{Cat}, \sim 65 \%$ on silica/alumina, surface area $190 \mathrm{~m}^{2} / \mathrm{g}$, Aldrich), were all used as received.

\subsection{Preparation of a-zirconium phosphate (ZrP)}

Layered a-zirconium phosphate ( $\mathrm{ZrP})$ is an alternative nanoplatelet to montmorillonite clay for developing the preliminary structure-property relationship of polymer/layered inorganic nanocomposites, since ZrP has exchangeable cations, narrow particle size distribution and controllable aspect ratio [18], [19], [20], [23], [24], [25] and [26]. In this work, ZrP was synthesized by refluxing zirconyl chloride $\left(\mathrm{ZrOCl}_{2} \cdot 8 \mathrm{H}_{2} \mathrm{O}, 98 \%\right.$, Aldrich) in $10 \mathrm{~mol} / \mathrm{L}$ phosphoric acid $\left(\mathrm{H}_{3} \mathrm{PO}_{4}, \geq 85 \%\right.$, solution in water, A.C.S. reagent, Sigma-Aldrich) for $24 \mathrm{~h}$ [26]. The XRD pattern shown in Fig. 1 confirmed the crystalline structure of ZrP. Ethylamine (75\%, solution in water, Aldrich) and three salts, hexadecyltrimethylammonium bromide (CTBA, $\mathrm{C}_{19} \mathrm{H}_{42} \mathrm{NBr}$, $\geq 98 \%$, Sigma), benzyldimethylhexadecylammonium chloride (HDBAC, $\mathrm{C}_{25} \mathrm{H}_{46} \mathrm{NCl} \cdot \mathrm{H}_{2} \mathrm{O}$, Sigma) and [3-(3,4-Dimethyl-9-oxo9H-thioxanthen-2-yloxy)-2-hydroxy-propyl] trimethylammonium chloride (DOHAC, $\mathrm{C}_{21} \mathrm{H}_{26} \mathrm{NClO}_{3} \mathrm{~S}, 97 \%$, Aldrich) were used as intercalating agents for preparation of organically-modified ZrP (OZrP) by cation exchange [27]. The structures of the salts are shown in Fig. 2 (A). Fig. 2(B) shows that the $d_{002}$ peak of OZrP (ZrP-CTBA, ZrPHDBAC and ZrP-DOHAC) shifts to the lower angle with increased interlayer spacing compared to ZrP, confirming the intercalation of the salts.

\subsection{Preparation of flame retardant PS composites}

The APP/TPE (IFR, 3/1 by weight) intumescent flame retarded PS/IFR composites were melt compounded using a Brabender mixer at $180{ }^{\circ} \mathrm{C}$ for $10 \mathrm{~min}$ at a screw speed of $60 \mathrm{rpm}$. To obtain the nanofillers and catalyst containing samples, these additives were firstly melt blended with PS for 5 min, IFR was then added and mixed for

Polymer Degradation and Stability, Vol. 95, No. 12 (December 2010): pg. 2388-2395. DOI. This article is (c) Elsevier and permission has been granted for this version to appear in e-Publications@Marquette. Elsevier does not grant permission for this article to be further copied/distributed or hosted elsewhere without the express permission from Elsevier. 
another 8 min. All formulations contain a total loading of $20 \%$; when a nanofiller is used together with the IFR, the IFR is reduced to maintain this total loading. All formulations are given in Table 1.

\subsection{Characterization}

The X-ray diffraction (XRD) data was obtained at room temperature using a Rigaku Miniflex II Desktop X-ray diffractometer equipped with a Cu-Ka source $(\lambda=1.5404 \AA)$. Thermogravimetric analyses (TGA) were conducted using a Netzsch TG209 F1 thermoanalyzer. The thermograms were obtained from 30 to $700{ }^{\circ} \mathrm{C}$ at a heating rate of $20^{\circ} \mathrm{C} / \mathrm{min}$ in a nitrogen atmosphere at a flow rate of $40 \mathrm{ml} / \mathrm{min}$. All specimens with mass of $15 \pm 1 \mathrm{mg}$ were run in duplicate and the average values are reported; the temperature is reproducible to $\pm 1{ }^{\circ} \mathrm{C}$ and the mass to $\pm 0.2 \%$. Pyrolysis combustion flow calorimetry experiments were carried out on a Govmark MCC-2 microscale combustion calorimeter (MCC). Samples weighing $4 \pm 1 \mathrm{mg}$ were heated to $750{ }^{\circ} \mathrm{C}$ at a heating rate of $1^{\circ} \mathrm{C} / \mathrm{s}$ in a stream of nitrogen flowing at $80 \mathrm{ml} / \mathrm{min}$. The combustor temperature was set at $900{ }^{\circ} \mathrm{C}$ and oxygen/nitrogen flow rate was set at $20 / 80 \mathrm{ml} / \mathrm{ml}$. The reported data are averages of 3-5 measurements and the typical relative error for heat release capacity is $\pm 10 \%$. The cone calorimeter experiments were performed on an Atlas Cone 2 instrument, according to ASTM E 1354, on $3 \mathrm{~mm}$ thick $100 \times 100 \mathrm{~mm}^{2}$ plaques at a heat flux of $35 \mathrm{~kW} / \mathrm{m}^{2}$. All samples were tested in triplicate and the data obtained are reproducible to within $\pm 10 \%$.

\section{Results and discussion}

\subsection{Flammability}

The influence of clay, MWNT, $\mathrm{Fe}_{2} \mathrm{O}_{3}, \mathrm{OZrP}$ and $\mathrm{Ni}$-Cat, on the flammability performance of PS/IFR composites obtained from cone calorimetry is summarized in Table 2 . The peak heat release rate (PHRR-Cone) of PS/IFR composite was reduced by $47 \%$ compared to pure PS at $15 \%$ IFR loading. Increasing the IFR loading did not bring about a significant reduction in PHRR-Cone; the reductions were $48 \%$ and $56 \%$ reduction at $20 \%$ and $30 \%$ loading, respectively.

Polymer Degradation and Stability, Vol. 95, No. 12 (December 2010): pg. 2388-2395. DOI. This article is @ Elsevier and permission has been granted for this version to appear in e-Publications@Marquette. Elsevier does not grant permission for this article to be further copied/distributed or hosted elsewhere without the express permission from Elsevier. 
NOT THE PUBLISHED VERSION; this is the author's final, peer-reviewed manuscript. The published version may be accessed by following the link in the citation at the bottom of the page.

Table 2 reveals that most of the composites in which some of the IFR is substituted by $1 \%$ and $2 \%$ of the nanoadditives at the same $20 \%$ global loading exhibit enhanced flame retardancy compared to sample PS/IFR-20, and the $2 \%$ substitution level provides a better flame retardant efficiency. The heat release rate (HRR) curves of PS/IFR composites containing $2 \%$ nanofillers and catalyst are shown in Fig. 3. When compared to PS/IFR-20 sample, it is clear that a longer flat portion with a constantly lower heat release rate appeared after the intumescent protective shield formed in all substituted samples except PS/IFR-18/ZrP-DOHAC-2, which confirms that the fire retardancy of PS/IFR-20 has been enhanced. This last mentioned sample gives poorer performance than PS-IFR-20.

The effects of these fillers on the reduction in PHRR-Cone of PS/IFR are compared in Fig. 4. Clay and Ni-Cat shows the highest efficiency in reducing the PHRR-Cone of PS/IFR composites, the PHRRCone is reduced by about $70 \%$ compared to pure PS and about $47 \%$ compared to the reference sample PS/IFR-20. The mechanism of the improved flame retardancy for IFR by the combination with clay and $\mathrm{Ni}$-Cat have been postulated to be the formation of an aluminophosphate structure and a catalytic effect in the cross-linking carbonization process [14] and [28].

For the sample PS/IFR-18/ $/ \mathrm{Fe}_{2} \mathrm{O}_{3}-2$, the peak HRR was reduced by $60 \%$ compared to PS/IFR-20, probably due to the modification of the intumescent char by the presence of metallic oxide. The combined effect of MWNT and IFR, PS/IFR-18/MWNT-2, gives a $60 \%$ reduction in peak HRR, which may be caused by a tighter char with higher mechanical strength [29].

The catalytic degradation of polypropylene (PP) macromolecules and the acceleration of the carbonization process induced by OZrP modified with CTBA has been reported in PP/APP/pentaerythritol system, which resulted in the sample PP/IFR (24\%)/OZrP (2.5\%) with UL-94 V-0 classification [6]. ZrP modified with different salts exhibited various effects on PS/IFR. The ZrP-CTBA and ZrP-HDBAC shows the same efficiency as MWNT and $\mathrm{Fe}_{2} \mathrm{O}_{3}$, but ZrP-DOHAC shows an antagonistic effect. In the case of PS/IFR-18/ZrP-DOHAC-2 sample, ZrP-DOHAC would prefer to disperse in the IFR phase rather than the PS matrix, due to its high polarity; this inhomogeneous distribution

Polymer Degradation and Stability, Vol. 95, No. 12 (December 2010): pg. 2388-2395. DOI. This article is (C) Elsevier and permission has been granted for this version to appear in e-Publications@Marquette. Elsevier does not grant permission for this article to be further copied/distributed or hosted elsewhere without the express permission from Elsevier. 
might account for the negative effect. The nanoplatelet of ZrP cannot efficiently insulate the underlying material and slow the escape of the volatile products [30]. Meanwhile, inter-chain bridges would be induced by the presence of $\mathrm{Zr}^{4+}$ and accelerate the cure reaction of the IFR compositions, which means that the solidification processes cannot be synchronous with the elimination of gaseous products to give the intumescence and form the multicellular structure [31]. As shown in Fig. 5, residues from PS/IFR-18/ZrP-DOHAC-2 did not generate an intumescent char or a coherent structure.

Photographs of the residual char collected from these composites after cone calorimetry are shown in Fig. 5. PS did not leave any residue, and the residues from the composites differ in appearance depending on the fillers. Sample PS/IFR-20 left a discontinuous intumescent char, and PS/IFR-18/MWNT-2 left an unfoamed char uniformly distributed on all of the surface of the aluminum container. Integrated intumescent char with few small holes covering the whole container were observed in samples PS/IFR18/Fe $\mathrm{O}_{3}-2$, PS/IFR-18/Ni-Cat-2 and PS/IFR-18/ZrP-CTBA-2, while a fraction of the container was not covered by the char from PS/IFR18/ZrP-HDBAC-2. In the case of PS/IFR-18/ZrP-DOHAC-2, a thin unfoamed char layer was left, which provided the substrate poor thermal protection. A distinct difference in appearance was observed in the char from PS/IFR-18/clay-2 which was intact with the highest expansion rate. As shown in Fig. 5, a large closed chamber supported by several pillars in the interior structure of the char was formed, where the "roof" and "floor" were made of multicellular foam. This pillared "Top-Bottom" intumescent char structure is therefore expected to have higher mechanical strength and long-term capability to impart fire prevention, which efficiently prolongs the burning process of the material.

\subsection{MCC studies}

The relevant parameters obtained from the MCC include peak heat release rate (PHRR-MCC), heat release capacity (HRC-MCC), total heat released (THR-MCC), temperature at PHRR ( $\left.T_{\mathrm{p}}-\mathrm{MCC}\right)$ and char yield. For the materials studied herein, PS, PS/IFR-20, PS/IFR-18/clay2, PS/IFR-18/MWNT-2 and PS/IFR-18/Fe $\mathrm{O}_{3}-2$, these parameters are collected in Table 3. The data show that the PHRR-MCC of pure PS is

Polymer Degradation and Stability, Vol. 95, No. 12 (December 2010): pg. 2388-2395. DOI. This article is (c) Elsevier and permission has been granted for this version to appear in e-Publications@Marquette. Elsevier does not grant permission for this article to be further copied/distributed or hosted elsewhere without the express permission from Elsevier. 
reduced by $47 \%$ by the addition of 20 wt $\%$ IFR. A further minor reduction in PHRR-MCC has been achieved by the introduction of clay ( $1 \%$ and $2 \%)$ and $\mathrm{Fe}_{2} \mathrm{O}_{3}(2 \%)$ in comparison with PS/IFR-20 sample. However, all the samples had the same char yields and the samples containing MWNT ( $1 \%$ and $2 \%$ ) and $\mathrm{Fe}_{2} \mathrm{O}_{3}(1 \%)$ exhibited higher PHRR-MCC, which suggests an antagonistic effect. The results, which are contrary to that from the cone calorimeter, confirm that MCC cannot be used to screen the intumescent flame retardant polymeric materials.

\subsection{Thermal degradation}

Fig. 6 shows the TGA curves of APP/TPE $(3.1597 \mathrm{~g} / 1.0527 \mathrm{~g})$, APP/TPE/clay (4.2748 g/1.4262 g/0.3021 g) and APP/TPE/ZrP-DOHAC $(4.2773 \mathrm{~g} / 1.4293 \mathrm{~g} / 0.3048 \mathrm{~g})$ intumescent flame retardant compounds, which were ground for 15 min to obtain a homogeneous mixture. For APP/TPE, the esterification process takes place in temperature range from 200 to $250{ }^{\circ} \mathrm{C}$, the carbonization process followed in the second stage at about $300{ }^{\circ} \mathrm{C}$ accompanied with the expansion caused by the evolution of gaseous products, and the intumescent materials begin to degrade above $450{ }^{\circ} \mathrm{C}$. The APP/TPE/clay and APP/TPE/ZrP-DOHAC compositions exhibit similar thermal degradation features to that of the APP/TPE composition below $450{ }^{\circ} \mathrm{C}$, which indicates that the clay and ZrP-DOHAC have little influence on the development of intumescence char. As the temperature is increased, the char from the APP/TPE/ZrP-DOHAC composition showed lower thermal stability compared to APP/TPE, while the char from APP/TPE/clay had higher thermal stability and an increased char yield.

The influence of the additives on the thermal degradation of PS composites is shown in Fig. 7. For all samples, the formation of an intumescent shield below $400{ }^{\circ} \mathrm{C}$ retards the degradation of PS in the higher temperature range and led to composites with $5-20{ }^{\circ} \mathrm{C}$ enhancement in $T_{\max }$ (the temperature obtained from DTG curves at which the maximum mass loss rate occurs). However, the introduction of these fillers did not change the thermal degradation process of PS/IFR. From the DTG curves, the peak temperature of the maximum weight loss rate $\left(T_{p}\right)$ of carbonaceous materials is found in the temperature range $450-550{ }^{\circ} \mathrm{C}$ in samples PS/IFR with MWNT, $\mathrm{Fe}_{2} \mathrm{O}_{3}$,

Polymer Degradation and Stability, Vol. 95, No. 12 (December 2010): pg. 2388-2395. DOI. This article is (c) Elsevier and permission has been granted for this version to appear in e-Publications@Marquette. Elsevier does not grant permission for this article to be further copied/distributed or hosted elsewhere without the express permission from Elsevier. 
OZrP and Ni-Cat, but not for sample PS/IFR-18/clay-2. The insert in Fig. 7 clearly shows this difference and confirms that clay imparts superior thermal stability.

\subsection{Correlation between TGA and cone}

The physical properties (yield, structure, mechanical properties, expansion ratio, etc.) and the chemical properties (thermal stability, thermal conductivity, etc.) of the intumescent char play an important role in the material fire performance [32]. Information on the thermal stability and the yield of the char can be obtained from the TGA and should allow for elucidation of their influence on the flammability.

Analysis of the data in Table 1 suggests that the char yields at $600{ }^{\circ} \mathrm{C}\left(\mathrm{Char}_{600^{\circ} \mathrm{C}}\right)$ from PS/IFR composites containing clay, MWNT, $\mathrm{Fe}_{2} \mathrm{O}_{3}, \mathrm{ZrP}-\mathrm{CTBA}, \mathrm{ZrP}-\mathrm{HDBAC}$ and $\mathrm{Ni}$-Cat, increases compared to PS/IFR-20, except for ZrP-DOHAC. The correlation between the Char $600^{\circ} \mathrm{C}$ and the PHRR-Cone reduction (PHRR-

Reduct $=\left(\right.$ PHRR $\left.\left._{\text {composites }}-\mathrm{PHRR}_{\mathrm{PS}}\right) / \mathrm{PHRR}_{\mathrm{PS}}\right)$ is shown in Fig. 8 and a high correlation coefficient, $R=0.9044$, is obtained, which suggests that the flame retardancy of the composites is improved with enhanced char yield from the combined intumescent flame retardant systems.

The influence of the thermal stability of the char on flammability is also studied. The thermal stability of char, which is represented by the change of char yields ( $\triangle$ Char) at $450{ }^{\circ} \mathrm{C}$ and $600^{\circ} \mathrm{C}$, is calculated

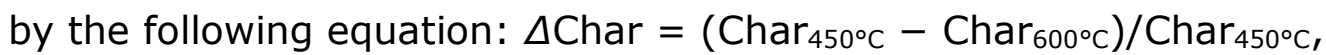

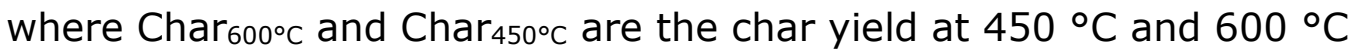
respectively. The lower is the value of $\Delta$ Char, the higher is the thermal stability of the char. As listed in Table 1, the char from PS/IFR with clay exhibits the best thermal stability, followed by the composites with $\mathrm{Ni}-\mathrm{Cat}, \mathrm{Fe}_{2} \mathrm{O}_{3}, \mathrm{MWNT}$ and $\mathrm{ZrP}-\mathrm{CTBA}$. However, there is no additional effect in improving the thermal stability of the char when ZrP-HDBAC and ZrP-DOHAC are present. Fig. 9 shows the correlation between PHRR-Reduct and $\triangle$ Char, the inverse proportion confirms that the higher thermal stability of the char will impart higher flame retardancy to the composites.

Polymer Degradation and Stability, Vol. 95, No. 12 (December 2010): pg. 2388-2395. DOI. This article is (c) Elsevier and permission has been granted for this version to appear in e-Publications@Marquette. Elsevier does not grant permission for this article to be further copied/distributed or hosted elsewhere without the express permission from Elsevier. 


\section{Conclusion}

Improvements in fire performance of PS/IFR composites by the partial substitution of nanofillers, including clay, OZrP, CNT, $\mathrm{Fe}_{2} \mathrm{O}_{3}$, and nickel catalyst have been reported. The char is one of the important aspects of flame retardancy. Compared to the PS/IFR composite, the presence of these additives change the structure, yield and thermal stability of the char, which leads to composites with different flammability performance. The montmorillonite clay containing sample showed the lowest flammability. The OZrP modified with different salts had various effects, depending on the cations, on the flame retardant efficiency of IFR system. The yield and thermal stability of the char based on TGA analyses correlated well with the reduction in peak HRR in cone calorimetry tests. A high correlation coefficient between the char yield and PHRR-Reduction ( $R=0.9044)$, and thermal stability of char and PHRR-Reduction $(R=-0.8754)$ were found.

\section{Acknowledgements}

The work was partially financially supported by the US Air Force under grant number FA8650-07-1-5901, the National Natural Science Foundation of China (No. 50903080), the China Postdoctoral Science Foundation (200902295), and the Program for Specialized Research Fund for the Doctoral Program of Higher Education (200803580008). The authors also gratefully thank Dr. Walid H. Awad for helpful discussions.

\section{References}

1. Horacek $\mathrm{H}$, Pieh $\mathrm{S}$. The importance of intumescent systems for fire protection of plastic materials. Polym Int 2000;49:1106-14.

2. Bourbigot S, Le Bras M, Duquesne S, Rochery M. Recent advances for intumescent polymers. Macromol Mater Eng 2004;289:499-511.

3. Morgan AB. Flame retarded polymer layered silicate nanocomposites: a review of commercial and open literature systems. Polym Adv Technol 2006;17:206-17.

4. Wang ZY, Han EH, Ke W. Fire-resistant effect of nanoclay on intumescent nanocomposite coatings. J Appl Polym Sci 2007;103:1681-9.

Polymer Degradation and Stability, Vol. 95, No. 12 (December 2010): pg. 2388-2395. DOI. This article is (c) Elsevier and permission has been granted for this version to appear in e-Publications@Marquette. Elsevier does not grant permission for this article to be further copied/distributed or hosted elsewhere without the express permission from Elsevier. 
NOT THE PUBLISHED VERSION; this is the author's final, peer-reviewed manuscript. The published version may be accessed by following the link in the citation at the bottom of the page.

5. Ma HY, Tong LF, Xu ZB, Fang ZP. Functionalizing carbon nanotubes by grafting on intumescent flame retardant: nanocomposite synthesis, morphology, rheology, and flammability. Adv Funct Mater 2008;18:414-21.

6. Yang DD, Hu Y, Song L, Nie SB, He SQ, Cai VB. Catalyzing carbonization function of a-ZrP based intumescent fire retardant polypropylene nanocomposites. Polym Degrad Stab 2008;93:2014-8.

7. Li GX, Yang JF, He TS, Wu YH, Liang GZ. An investigation of the thermal degradation of the intumescent coating containing $\mathrm{MoO} 3$ and $\mathrm{Fe} 2 \mathrm{O} 3$. Surf Coatings Technol 2008;202:3121-8.

8. Lv P, Wang ZZ, Hu Y, Yu M. "Effect of metallic oxides in polypropylene composites containing melamine phosphate and pentaerythritol". Plas Rubber Compos 2008;37:311-8.

9. Lewin M. Synergism and catalysis in flame retardancy of polymers. Polym Adv Technol 2001;12:215-22.

10. Lewin M, Endo M. Catalysis of intumescent flame retardancy of polypropylene by metallic compounds. Polym Adv Technol 2003;14:311.

11. Song RJ, Zhang BY, Huang BT, Tang T. Synergistic effect of supported nickel catalyst with intumescent flame-retardants on flame retardancy and thermal stability of polypropylene. J Appl Polym Sci 2006;102:5988-93.

12. Wilkie CA, Chigwada G. Gilman JW, Lyon RE. High-throughput techniques for the evaluation of fire retardancy. J Mater Chem 2006;16:2023-30.

13. Gilman JW, Bourbigot S, Shields JR, Nyden M, Kashiwagi T, Davis RD, et al. High throughput methods for polymer nanocomposites research: extrusion, NMR characterization and flammability property screening. J Mater Sci 2003;38:4451-60.

14. Gilman JW, Davis RD, Shields JR, Wentz D, Brassell LD, Morgan AB, et al. Development of high throughput methods for polymer flammability property characterization. SAMPE Conference Proceedings 2004;49:460-469.

15. Nyden MR, Gilman JW, Davis RD, Shields J.R. High-throughput methods for flammability screening of multicomponent polymer blends and nanocomposites, International SAMPE Symposium and Exhibition

Polymer Degradation and Stability, Vol. 95, No. 12 (December 2010): pg. 2388-2395. DOI. This article is (c) Elsevier and permission has been granted for this version to appear in e-Publications@Marquette. Elsevier does not grant permission for this article to be further copied/distributed or hosted elsewhere without the express permission from Elsevier. 
NOT THE PUBLISHED VERSION; this is the author's final, peer-reviewed manuscript. The published version may be accessed by following the link in the citation at the bottom of the page.

(2002), 47 (Affordable Materials Technology: Platform to Global Value and Performance, Book 2),738-748.

16. Lyon RE, Walters RN, Stoliarov SI. Screening flame retardants for plastics using microscale combustion calorimetry. Polym Eng Sci 2007;47(10):1501-10.

17. Hergenrother PM, Thompson CM, Smith JG, Connell JW, Hinkley JA, Lyon $\mathrm{RE}$, et al. Flame retardant aircraft epoxy resins containing phosphorus. Polymer 2005;46:5012-24.

18. Cogen JM, Lin TS, Lyon RE. Correlaions between pyrolysis combustion now calorimetry and conventional flammability tests with halogen-free flame retardant polyolefin compounds. Fire Mater 2009;33:33-50.

19. Lu HD, Wilkie CA. Synergistic effect of carbon nanotubes and decabromodiphenyl oxide/Sb2O3 in improving the flame retardancy of polystyrene. Polym Degrad Stab 2010;95:564-71.

20. Schartel B, Pawlowski KH, Lyon RE. Pyrolysis combustion flow calorimeter: a tool to assess flame retarded PC/ABS materials. Thermochimica Acta 2007;462:1-14.

21. Jimenez M, Duquesne S, Bourbigot S. High-throughput fire testing for intumescent coatings. Ind Eng Chern Res 2006;45:7475-81.

22. (a) Huang $\mathrm{YH}$, Serageldin MA. A simple-model for predicting polymer ignition in a thermogravimetric analyzer. Thermochimica Acta 1987;112:161-9: (b) Costache MC, Wilkie CA. High-throughput method for estimating the time to sustained ignition of polystyreneclay nanocomposites based on thermogravimetric analysis. Polym Adv Technol 2010;21:506-11.

23. Trobajo C, Khainakov SA, Espina A., Garcla JR. On the synthesis of azirconium phosphate. Chem Mater 2000;12:1787-90.

24. Boo WJ, Sun LY, Liu J, Clearfield A, Sue H-J, Mullins MJ, et al. Morphology and mechanical behavior of exfoliated epoxy/a-zirconium phosphate nano-composites. Comp Sci Technol 2007;67:262-9.

25. Sue H-J, Gam KT. Epoxy nanocomposites based on the synthetic azirconium phosphate layer structure. Chem Mater 2004;16:242-9.

Polymer Degradation and Stability, Vol. 95, No. 12 (December 2010): pg. 2388-2395. DOI. This article is (c) Elsevier and permission has been granted for this version to appear in e-Publications@Marquette. Elsevier does not grant permission for this article to be further copied/distributed or hosted elsewhere without the express permission from Elsevier. 
NOT THE PUBLISHED VERSION; this is the author's final, peer-reviewed manuscript. The published version may be accessed by following the link in the citation at the bottom of the page.

26. Sun L, Boo WJ, Sue HJ, Clearfield A. Preparation of a-zirconium phosphate nanoplatelets with wide variations in aspect ratios. New J Chem 2007;31:39-43.

27. Zhang R, Hu Y, Li BG, Chen ZY, Fan WC. Study on the preparation and structure of polyacrylamide/a-zirconium phosphate nanocomposites. J Mater Sci 2007;42:5641-6.

28. Tang Y, Hu Y, Wang SF, Gui Z, Chen ZY, Fan WC. Intumescent flame retardant-montmorillonite synergism in polypropylene-layered silicate nanocomposites. Polym Int 2003;52:1396-400.

29. Marosi G, Marton A, Szep A, Csontos I, Keszei S, Zimonyi E, et al. Fire retardancy effect of migration in polypropylene nanocomposites induced by modified interlayer. Polym Degrad Stab 2003;2003(82):379-85.

30. Chen YJ, Fang ZP, Yang CZ, Wang Y, Guo ZH, Zhang Y. Effect of clay dispersion on the synergism between clay and intumescent flame retardants in polystyrene. J Appl Polym Sci 2010;115:777-83.

31. Gibov KM, Mamleev VS, The kinetics of crosslinking in process of intumescence of fireproof polymer compositions. J Appl Polym Sci 1997;66:329-38.

32. Bourbigot $S$, Duquesne $S$, Intumescent-based fire retardants. In: Wilkie $C A$, Morgan $A B$, editors. Fire retardancy of polymeric materials. Taylor and Francis Group; 2010. p. 129-62.

\section{About the Authors}

Charles A. Wilkie : Department of Chemistry and Fire Retardant Research Facility, Marquette University, P.O. 1881, Milwaukee, WI 53201-1881, USA

Tel.: +1 414288 7239; fax: +1 4142887066 .

Email: charles.wilkie@marquette.edu

Hongdian Lu : Department of Chemical and Materials Engineering, Hefei University, Hefei, Anhui, 230022, PR China and State Key Laboratory of Fire Science, University of Science and Technology of China, Hefei, Anhui, 230026, PR China.

Polymer Degradation and Stability, Vol. 95, No. 12 (December 2010): pg. 2388-2395. DOI. This article is (C) Elsevier and permission has been granted for this version to appear in e-Publications@Marquette. Elsevier does not grant permission for this article to be further copied/distributed or hosted elsewhere without the express permission from Elsevier. 
NOT THE PUBLISHED VERSION; this is the author's final, peer-reviewed manuscript. The published version may be accessed by following the link in the citation at the bottom of the page.

\section{Appendix}

Table 1: Compositions and TGA results of intumescent flame retardant PS composites

\begin{tabular}{|c|c|c|c|c|c|c|c|c|c|c|c|c|}
\hline \multirow[t]{2}{*}{ Sample } & \multicolumn{8}{|c|}{ Formulations (wt\%) } & \multicolumn{4}{|l|}{ TGA result } \\
\hline & IFR & clay & MWNT & $\mathrm{Fe}_{2} \mathrm{O}_{3}$ & Ni-Cat & $\mathrm{ZrP}-\mathrm{CTBA}$ & ZrP-HDBAC & ZrP-DOHAC & $T_{\max }\left({ }^{\circ} \mathrm{C}\right)$ & $\mathrm{T}_{\text {char }}\left({ }^{\circ} \mathrm{C}\right)$ & Char $\left(\%, 450^{\circ} \mathrm{C}\right)$ & $\operatorname{Char}\left(\%, 600^{\circ} \mathrm{C}\right)(\Delta$ char $)$ \\
\hline PS & $\mathrm{NA}$ & & & & & & & & 403 & NA & NA & NA \\
\hline PS/IFR-20 & 20 & & & & & & & & 419 & 490 & 12 & $6(50 \%)$ \\
\hline PS/IFR-18/clay-2 & 18 & 2 & & & & & & & 420 & NA & 13 & $11(15 \%)$ \\
\hline PS/IFR-18/MWNT-2 & 18 & & 2 & & & & & & 418 & 535 & 15 & $9(40 \%)$ \\
\hline $\mathrm{PS} / \mathrm{IFR}-18 / \mathrm{Fe}_{2} \mathrm{O}_{3}-2$ & 18 & & & 2 & & & & & 408 & 497 & 13 & $8(38 \%)$ \\
\hline PS/IFR-18/Ni-Cat-2 & 18 & & & & 2 & & & & 418 & 523 & 13 & $9(31 \%)$ \\
\hline PS/IFR-18/ZrP-CTBA-2 & 18 & & & & & 2 & & & 418 & 480 & 13 & $7(46 \%)$ \\
\hline PS/IFR-18/ZrP-HDBAC-2 & 18 & & & & & & 2 & & 419 & 500 & 14 & $7(50 \%)$ \\
\hline PS/IFR-18/ZrP-DOHAC-2 & 18 & & & & & & & 2 & 419 & 491 & 12 & $5(58 \%)$ \\
\hline
\end{tabular}

Tmax: the temperature obtained from DTG curves at which the maximum mass loss rate occurs;

Tchar: the degradation temperature of char obtained from DTG curves; $\Delta$ char: (Char600 $\left.{ }^{\circ} \mathrm{C}-\mathrm{Char} 40^{\circ} \mathrm{C}\right) / \mathrm{Char} 450^{\circ} \mathrm{C}$.

Table 2: Cone calorimetric data for intumescent flame retardant PS composites at $35 \mathrm{~kW} / \mathrm{m} 2$

\begin{tabular}{|c|c|c|c|c|c|c|c|c|c|}
\hline \multirow[b]{2}{*}{ Sample } & \multicolumn{9}{|l|}{ (a) } \\
\hline & PHRR $\left(\mathrm{kW} / \mathrm{m}^{2}\right)$ & $t_{p}(s)$ & $\operatorname{THR}\left(\mathrm{MJ} / \mathrm{m}^{2}\right)$ & AEHC (MJ $/ \mathrm{kg})$ & $\operatorname{ASEA}\left(\mathrm{m}^{2} / \mathrm{kg}\right)$ & $\operatorname{AMLR}\left(\mathrm{g} / \mathrm{m}^{2} \mathrm{~s}\right)$ & $t_{\text {ign }}(s)$ & \multicolumn{2}{|c|}{ Reduct-Cone (vs PS, \%) } \\
\hline pure PS & $1166 \pm 93$ & \multirow{2}{*}{$\begin{array}{l}180 \pm 14 \\
118 \pm 27\end{array}$} & $101 \pm 5$ & $28 \pm 6$ & $1008 \pm 221$ & $27 \pm 2$ & $44 \pm 10$ & \multicolumn{2}{|c|}{$\mathrm{NA}$} \\
\hline PS/IFR-15 & $617 \pm 88$ & & $78 \pm 10$ & $1964 \pm 465$ & $27 \pm 4$ & $21 \pm 1$ & $\begin{array}{l}44 \pm 10 \\
33 \pm 2\end{array}$ & \multicolumn{2}{|c|}{47} \\
\hline PS/IFR-20 & $601 \pm 23$ & $67 \pm 8$ & \multirow{2}{*}{$\begin{array}{l}73 \pm 4 \\
68 \pm 7\end{array}$} & $1078 \pm 213$ & $23 \pm 5$ & $19 \pm 2$ & $\begin{array}{l}33 \pm 2 \\
34 \pm 3\end{array}$ & \multicolumn{2}{|c|}{48} \\
\hline PS/IFR-30 & $515 \pm 45$ & $55 \pm 3$ & & $1954 \pm 428$ & $26 \pm 1$ & $17 \pm 1$ & $36 \pm 2$ & 56 & \\
\hline PS/IFR-19/clay-1 & $333 \pm 33$ & $201 \pm 3$ & $72 \pm 8$ & $2236 \pm 1015$ & $27 \pm 3$ & $11 \pm 0$ & $34 \pm 1$ & 71 & \\
\hline PS/IFR-18/clay-2 & $320 \pm 4$ & $225 \pm 12$ & $77 \pm 0$ & $1227 \pm 163$ & $27 \pm 2$ & $10 \pm 1$ & $34 \pm 1$ & 73 & \\
\hline PS/IFR-19/MWNT-1 & $519 \pm 24$ & $50 \pm 19$ & $71 \pm 1$ & $1628 \pm 17$ & $26 \pm 0$ & $17 \pm 1$ & $26 \pm 4$ & 55 & \\
\hline PS/IFR-18/MWNT-2 & $457 \pm 51$ & $41 \pm 3$ & $69 \pm 5$ & $1629 \pm 111$ & $26 \pm 2$ & $15 \pm 1$ & $32 \pm 3$ & 61 & \\
\hline $\mathrm{PS} / \mathrm{IFR}-19 / \mathrm{Fe}_{2} \mathrm{O}_{3}-1$ & $456 \pm 30$ & $78 \pm 9$ & $74 \pm 1$ & $1933 \pm 466$ & $28 \pm 1$ & $15 \pm 1$ & $28 \pm 4$ & 61 & \\
\hline $\mathrm{PS} / \mathrm{IFR}-18 / \mathrm{Fe}_{2} \mathrm{O}_{3}-2$ & $467 \pm 23$ & $37 \pm 4$ & $75 \pm 5$ & $2317 \pm 652$ & $28 \pm 2$ & $15 \pm 1$ & $32 \pm 4$ & 60 & \\
\hline PS/IFR-19/Ni-Cat-1 & $398 \pm 39$ & $42 \pm 8$ & $73 \pm 5$ & $2024 \pm 338$ & $27 \pm 2$ & $14 \pm 1$ & $28 \pm 3$ & 66 & \\
\hline PS/IFR-18/Ni-Cat-2 & $324 \pm 7$ & $75 \pm 43$ & $63 \pm 4$ & $1855 \pm 590$ & $23 \pm 1$ & $13 \pm 1$ & $23 \pm 1$ & 72 & \\
\hline & (b) & & & & & & & & \\
\hline Sample & PHRR $\left(\mathrm{kW} / \mathrm{m}^{2}\right)$ & $t_{p}(s)$ & $\mathrm{THR}\left(\mathrm{MJ} / \mathrm{m}^{2}\right.$ & $\mathrm{AEHC}(\mathrm{MJ} / \mathrm{kg}$ & ASEA $\left(\mathrm{m}^{2} / \mathrm{kg}\right)$ & $\operatorname{AMLR}\left(\mathrm{g} / \mathrm{m}^{2}\right.$ & & $\mathrm{t}_{\text {ign }}(\mathrm{s})$ & Reduct-Cone (\%) \\
\hline pure PS & $1105 \pm 44$ & $136 \pm 7$ & $90 \pm 4$ & $30 \pm 1$ & $1087 \pm 15$ & & & & NA \\
\hline PS/IFR-20\% & $629 \pm 13$ & $120 \pm 21$ & $72 \pm 3$ & $27 \pm 1$ & $1161 \pm 48$ & $20 \pm 1$ & & $34 \pm 6$ & 43 \\
\hline PS/IFR-19/clay-1 & $382 \pm 43$ & $61 \pm 2$ & $73 \pm 1$ & $27 \pm 1$ & $1294 \pm 28$ & $11 \pm 0$ & & $44 \pm 3$ & 65 \\
\hline PS/IFR-18/clay-2 & $332 \pm 7$ & $58 \pm 2$ & $77 \pm 6$ & $31 \pm 1$ & $1321 \pm 33$ & $9 \pm 1$ & & $42 \pm 5$ & 70 \\
\hline PS/IFR-19/ZrP-CTBA-1 & $495 \pm 12$ & $71 \pm 6$ & $72 \pm 1$ & $28 \pm 1$ & $1394 \pm 28$ & $16 \pm 1$ & & $38 \pm 4$ & 55 \\
\hline PS/IFR-18/ZrP-CTBA-2 & $421 \pm 42$ & $61 \pm 6$ & $72 \pm 2$ & $26 \pm 1$ & $1405 \pm 47$ & $15 \pm 1$ & & $37 \pm 7$ & 62 \\
\hline PS/IFR-19/ZrP-HDBAC-1 & $537 \pm 15$ & $64 \pm 4$ & $71 \pm 2$ & $27 \pm 1$ & $1385 \pm 5$ & $17 \pm 1$ & & $37 \pm 1$ & 51 \\
\hline PS/IFR-18/ZrP-HDBAC-2 & $488 \pm 11$ & $60 \pm 4$ & $74 \pm 4$ & $27 \pm 2$ & $1528 \pm 41$ & $16 \pm 1$ & & $36 \pm 3$ & 56 \\
\hline PS/IFR-19/ZrP-DOHAC-1 & $688 \pm 35$ & $81 \pm 5$ & $73 \pm 2$ & $29 \pm 2$ & $1405 \pm 28$ & $21 \pm 1$ & & $43 \pm 4$ & 38 \\
\hline PS/IFR-18/ZrP-DOHAC-2 & $703 \pm 24$ & $96 \pm 17$ & $80 \pm 3$ & $26 \pm 5$ & $1296 \pm 273$ & $21 \pm 1$ & & $41 \pm 3$ & 36 \\
\hline
\end{tabular}

PHRR, peak heat release rate; tp, time to peak heat release rate; THR, total heat released; AEHC, average effective heat of combustion; ASEA, average specific extinction area; AMLR, average mass loss rate; tign, time to ignition; FPI, fire performance index, tign/PHRR; FIGRA, fire growth rate, PHRR/tp; Reduct-Cone, $100 \mathrm{x}$ (PHRRPS - PHRRcomposite)/PHRRPS.

Polymer Degradation and Stability, Vol. 95, No. 12 (December 2010): pg. 2388-2395. DOI. This article is (c) Elsevier and permission has been granted for this version to appear in e-Publications@Marquette. Elsevier does not grant permission for this article to be further copied/distributed or hosted elsewhere without the express permission from Elsevier. 
NOT THE PUBLISHED VERSION; this is the author's final, peer-reviewed manuscript. The published version may be accessed by following the link in the citation at the bottom of the page.

Table 3: The MCC data of selected intumescent flame retardant PS composites

\begin{tabular}{lclllll}
\hline Sample & PHRR $(\mathrm{W} / \mathrm{g})$ & HRC $(\mathrm{J} / \mathrm{g} \cdot \mathrm{k})$ & $\mathrm{THR}(\mathrm{k} / \mathrm{g})$ & $\mathrm{T}_{\mathrm{p}}\left({ }^{\circ} \mathrm{C}\right)$ & Char $(\%)$ & Reduct-MCC $(\%)$ \\
\hline pure PS & $1046 \pm 8$ & $1026 \pm 8$ & $38 \pm 0$ & $441 \pm 1$ & NA & NA \\
PS/IFR-20 & $554 \pm 75$ & $589 \pm 4$ & $30 \pm 0$ & $452 \pm 2$ & $9 \pm 1$ & 47 \\
PS/IFR-19/clay-1 & $528 \pm 30$ & $555 \pm 7$ & $31 \pm 1$ & $455 \pm 2$ & $9 \pm 1$ & 50 \\
PS/IFR-18/clay-2 & $526 \pm 26$ & $534 \pm 14$ & $31 \pm 0$ & $441 \pm 8$ & $9 \pm 1$ & 50 \\
PS/IFR-19/MWNT-1 & $581 \pm 24$ & $575 \pm 21$ & $30 \pm 0$ & $451 \pm 2$ & $9 \pm 0$ & 44 \\
PS/IFR-18/MWNT-2 & $605 \pm 31$ & $597 \pm 30$ & $30 \pm 0$ & $448 \pm 5$ & $9 \pm 2$ & 42 \\
PS/IFR-19/Fe $20_{3}-1$ & $581 \pm 6$ & $575 \pm 6$ & $31 \pm 0$ & $451 \pm 1$ & $9 \pm 1$ & 44 \\
PS/IFR-18/Fe $2 \mathrm{~F}_{3}-2$ & $536 \pm 37$ & $546 \pm 15$ & $31 \pm 1$ & $449 \pm 2$ & $9 \pm 1$ & 49 \\
\hline
\end{tabular}

PHRR, peak heat release rate; HRC, heat release capacity; THR, total heat released; Reduct-MCC, $100 \times$ (PHRRPS - PHRRcomposite)/PHRRPS, Tp, temperature at PHRR.

Fig. 1.: The XRD pattern of ZrP

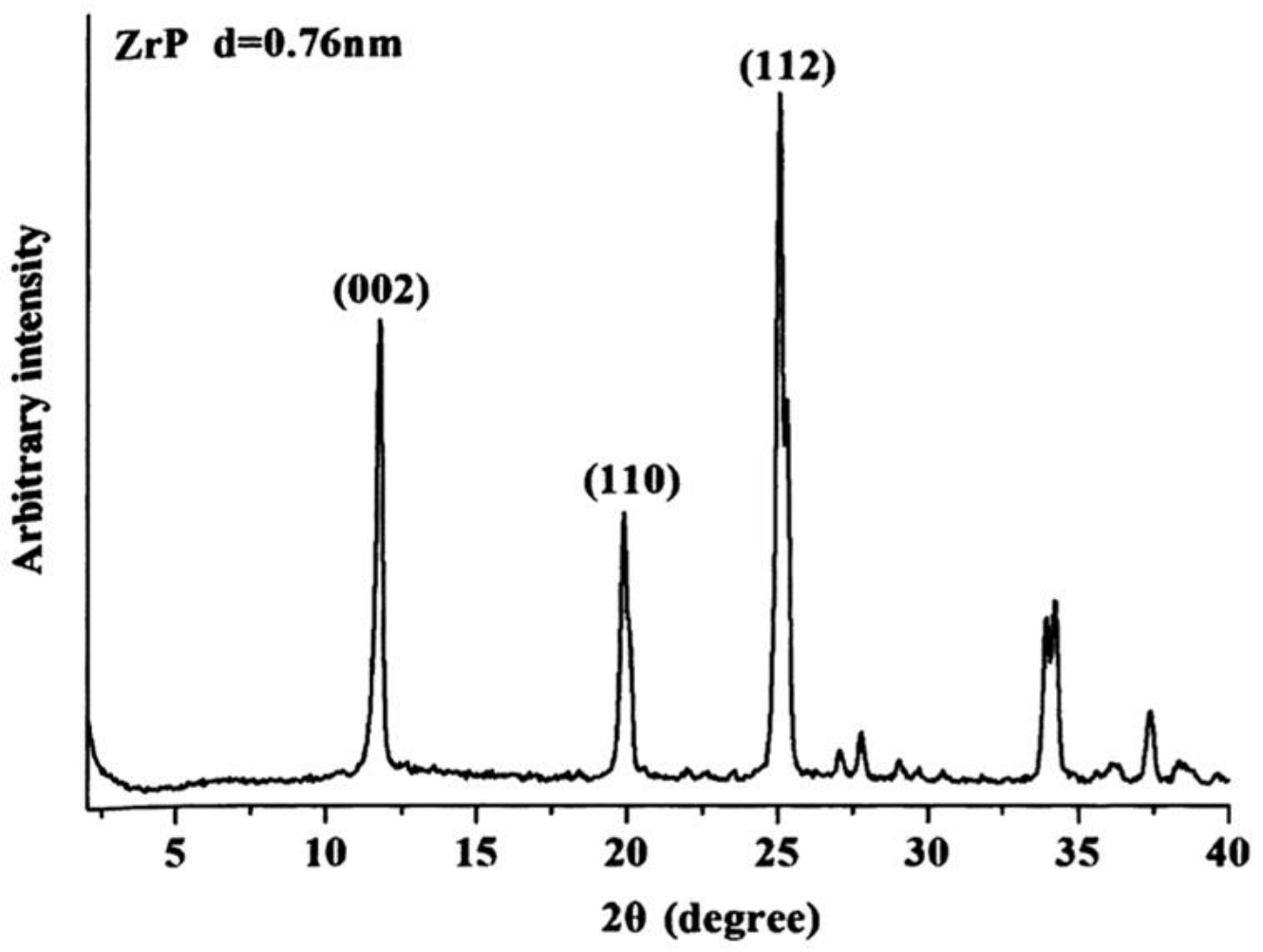

Polymer Degradation and Stability, Vol. 95, No. 12 (December 2010): pg. 2388-2395. DOI. This article is (c) Elsevier and permission has been granted for this version to appear in e-Publications@Marquette. Elsevier does not grant permission for this article to be further copied/distributed or hosted elsewhere without the express permission from Elsevier. 
NOT THE PUBLISHED VERSION; this is the author's final, peer-reviewed manuscript. The published version may be accessed by following the link in the citation at the bottom of the page.

Fig. 2.: (A) Structure of the salts used to modify zirconium phosphate, and (B) the XRD patterns of organically-modified ZrP (OZrP)

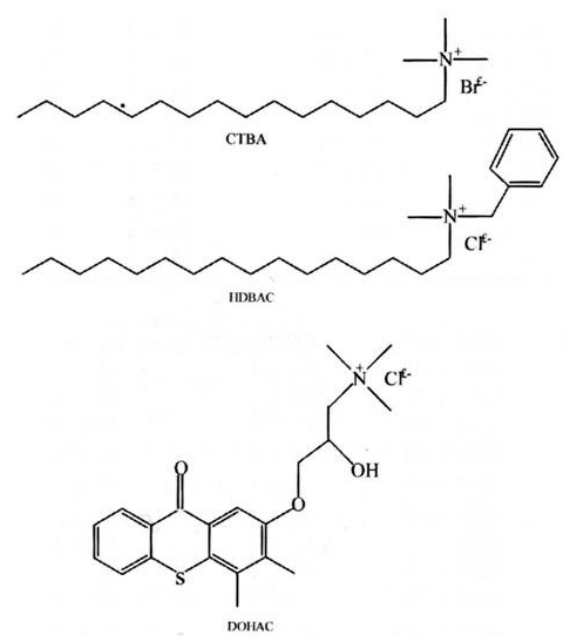

A

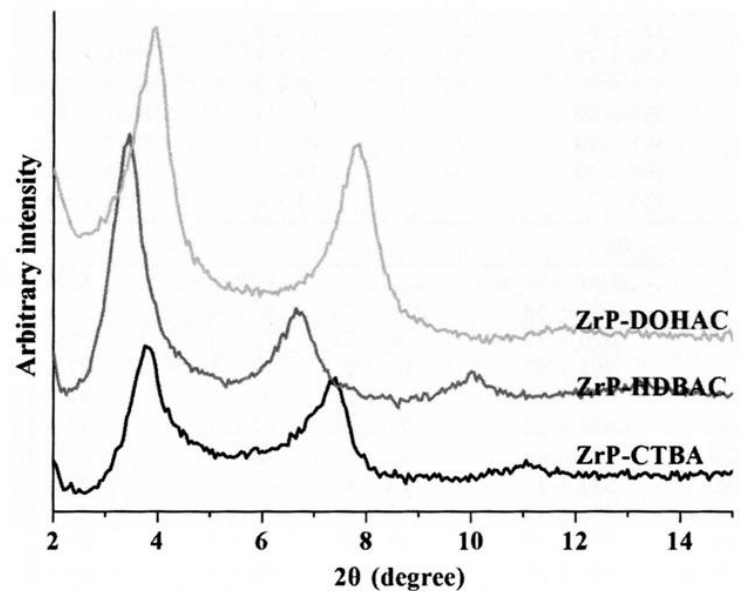

B

Fig. 3.: HRR curves for intumescent flame retarded PS composites

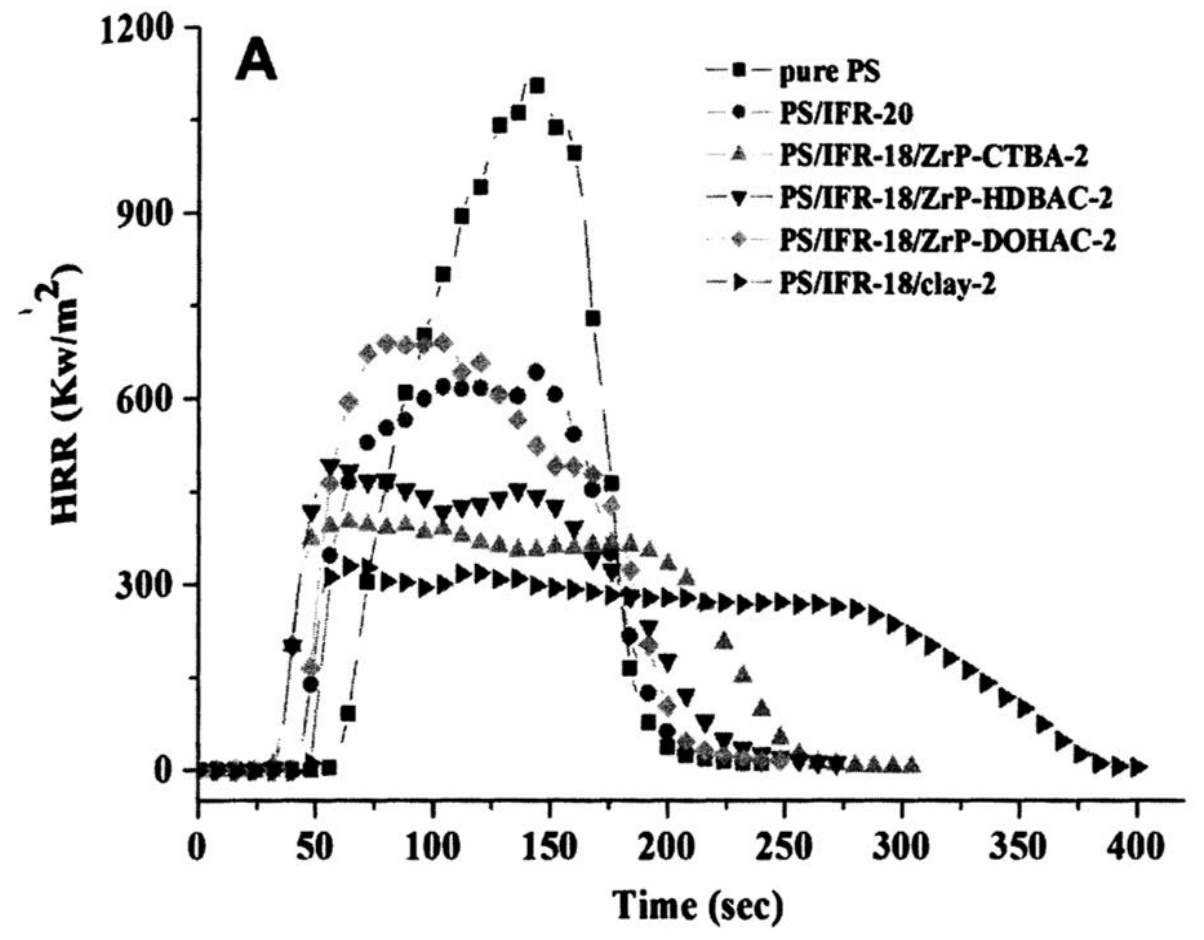

Polymer Degradation and Stability, Vol. 95, No. 12 (December 2010): pg. 2388-2395. DOI. This article is (c) Elsevier and permission has been granted for this version to appear in e-Publications@Marquette. Elsevier does not grant permission for this article to be further copied/distributed or hosted elsewhere without the express permission from Elsevier. 
NOT THE PUBLISHED VERSION; this is the author's final, peer-reviewed manuscript. The published version may be accessed by following the link in the citation at the bottom of the page.

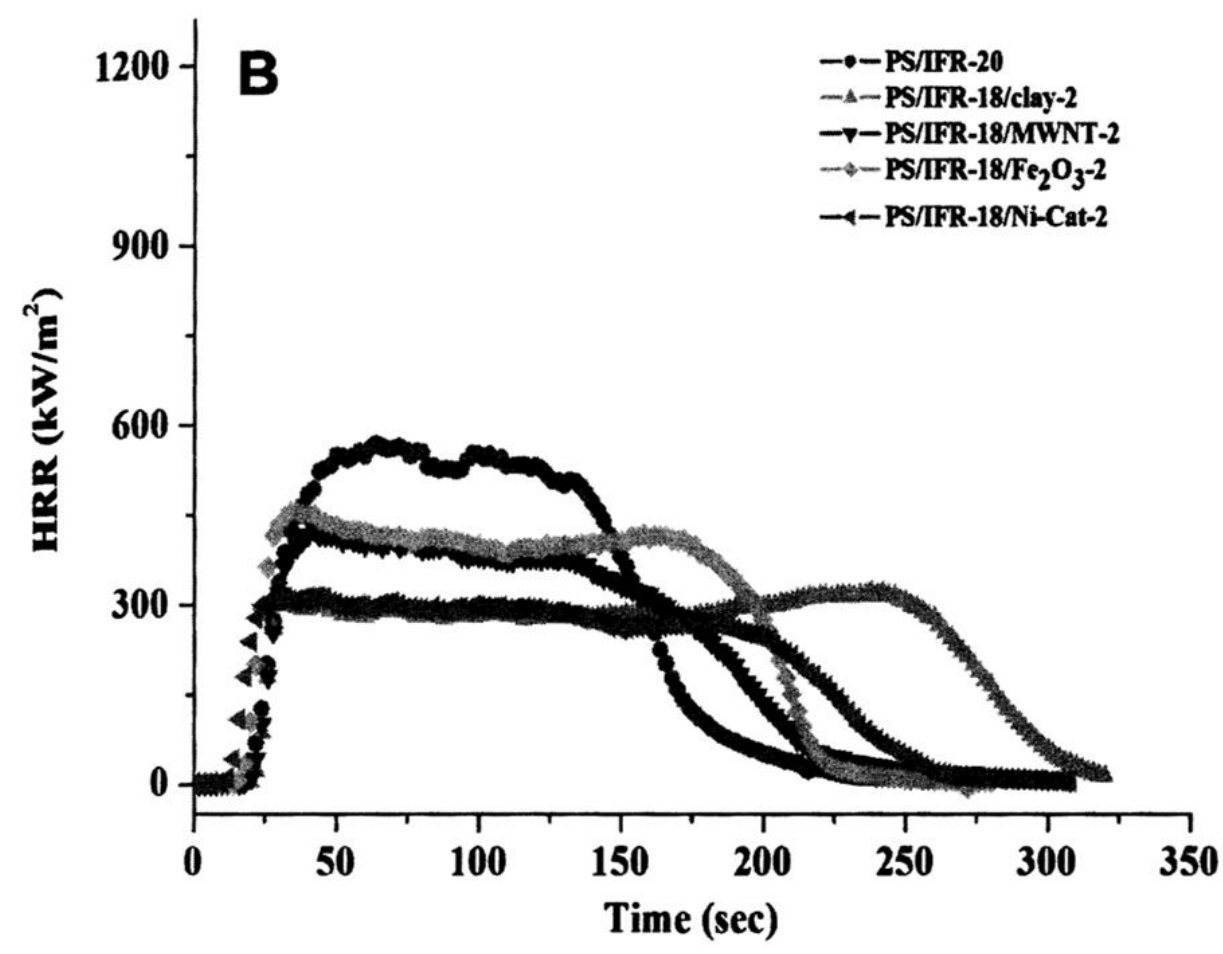

Fig. 4.: The influence of additives on the reduction in peak HRR-Cone for intumescent flame retarded PS composites at the same global loading (20 wt\%)

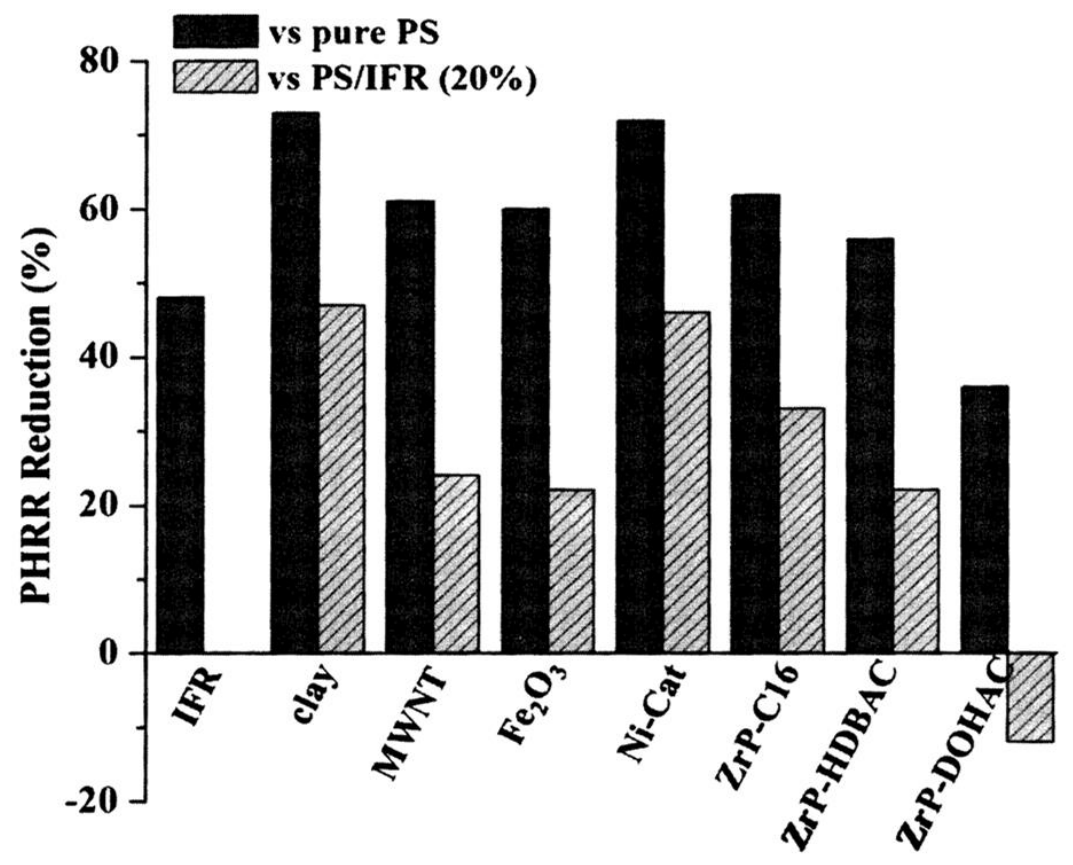

Polymer Degradation and Stability, Vol. 95, No. 12 (December 2010): pg. 2388-2395. DOI. This article is (c) Elsevier and permission has been granted for this version to appear in e-Publications@Marquette. Elsevier does not grant permission for this article to be further copied/distributed or hosted elsewhere without the express permission from Elsevier. 
NOT THE PUBLISHED VERSION; this is the author's final, peer-reviewed manuscript. The published version may be accessed by following the link in the citation at the bottom of the page.

Fig. 5.: Photographs of residue chars from intumescent flame retardant PS composites with various additives after cone calorimeter tests

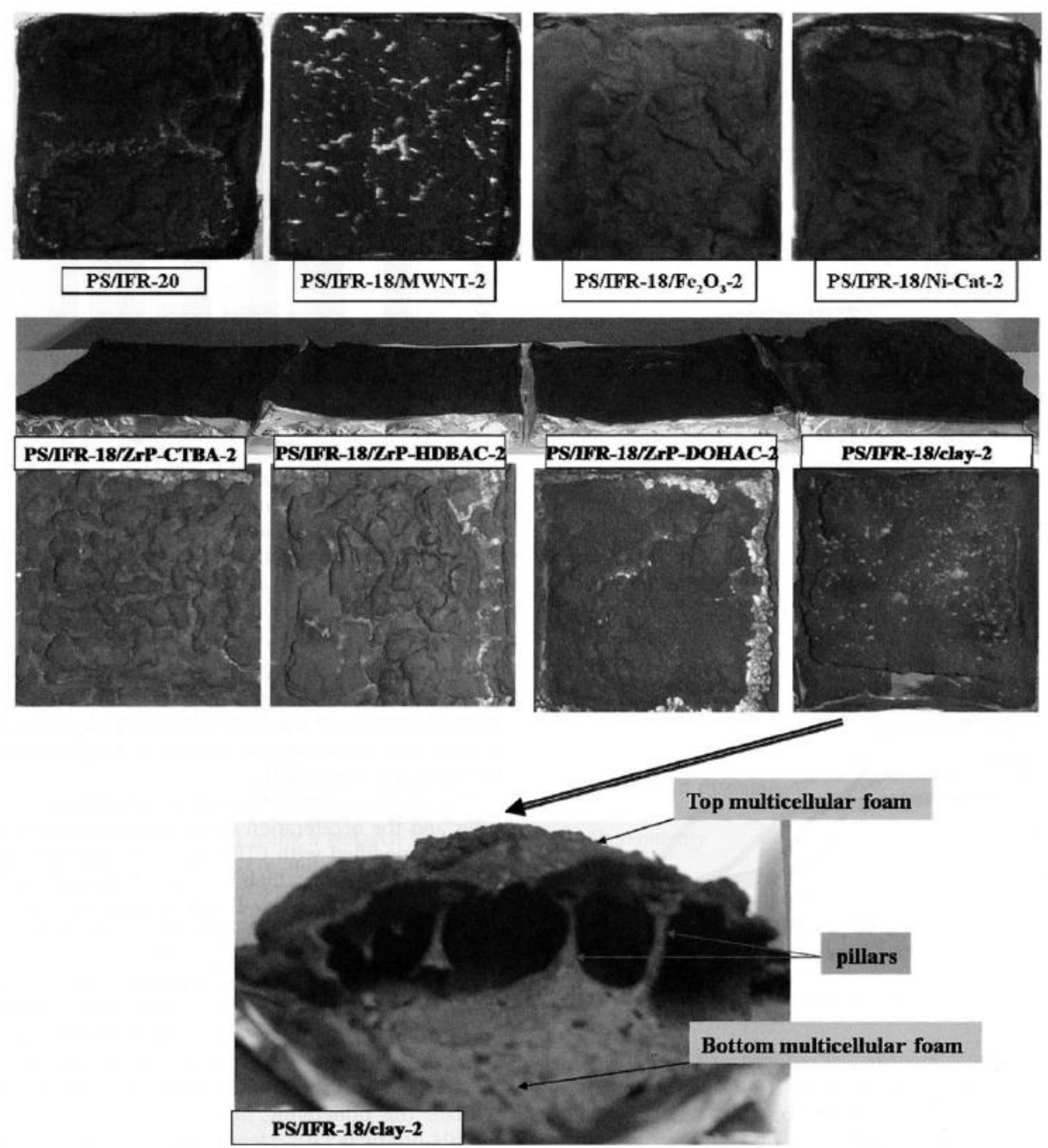

Polymer Degradation and Stability, Vol. 95, No. 12 (December 2010): pg. 2388-2395. DOI. This article is @ Elsevier and permission has been granted for this version to appear in e-Publications@Marquette. Elsevier does not grant permission for this article to be further copied/distributed or hosted elsewhere without the express permission from Elsevier. 
NOT THE PUBLISHED VERSION; this is the author's final, peer-reviewed manuscript. The published version may be accessed by following the link in the citation at the bottom of the page.

Fig. 6.: TGA curves of IFR (APP(TPE $=3 / 1$ by weight), IFR/clay and IFR/ZrP-DOHAC compositions

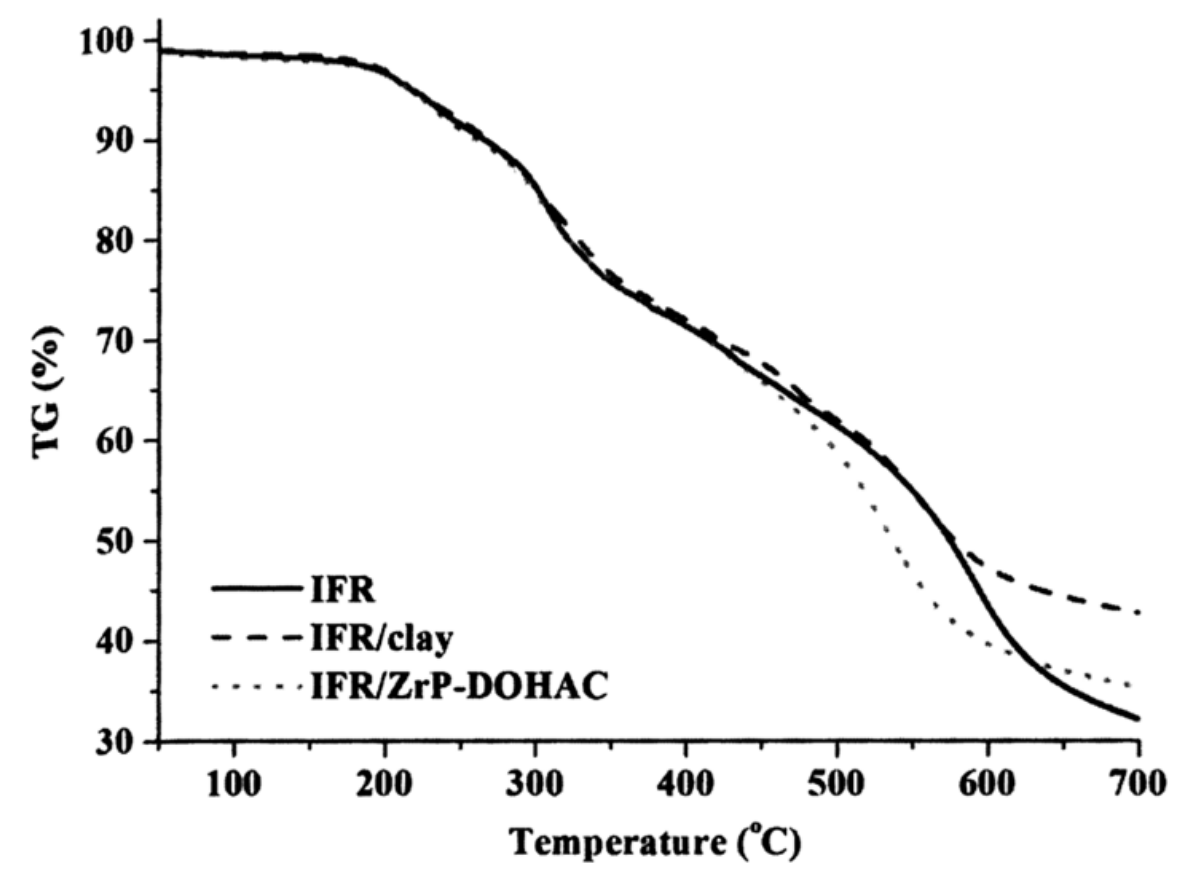

Polymer Degradation and Stability, Vol. 95, No. 12 (December 2010): pg. 2388-2395. DOI. This article is @ Elsevier and permission has been granted for this version to appear in e-Publications@Marquette. Elsevier does not grant permission for this article to be further copied/distributed or hosted elsewhere without the express permission from Elsevier. 
NOT THE PUBLISHED VERSION; this is the author's final, peer-reviewed manuscript. The published version may be accessed by following the link in the citation at the bottom of the page.

Fig. 7.: TGA and DTG curves for intumescent flame retarded PS composites

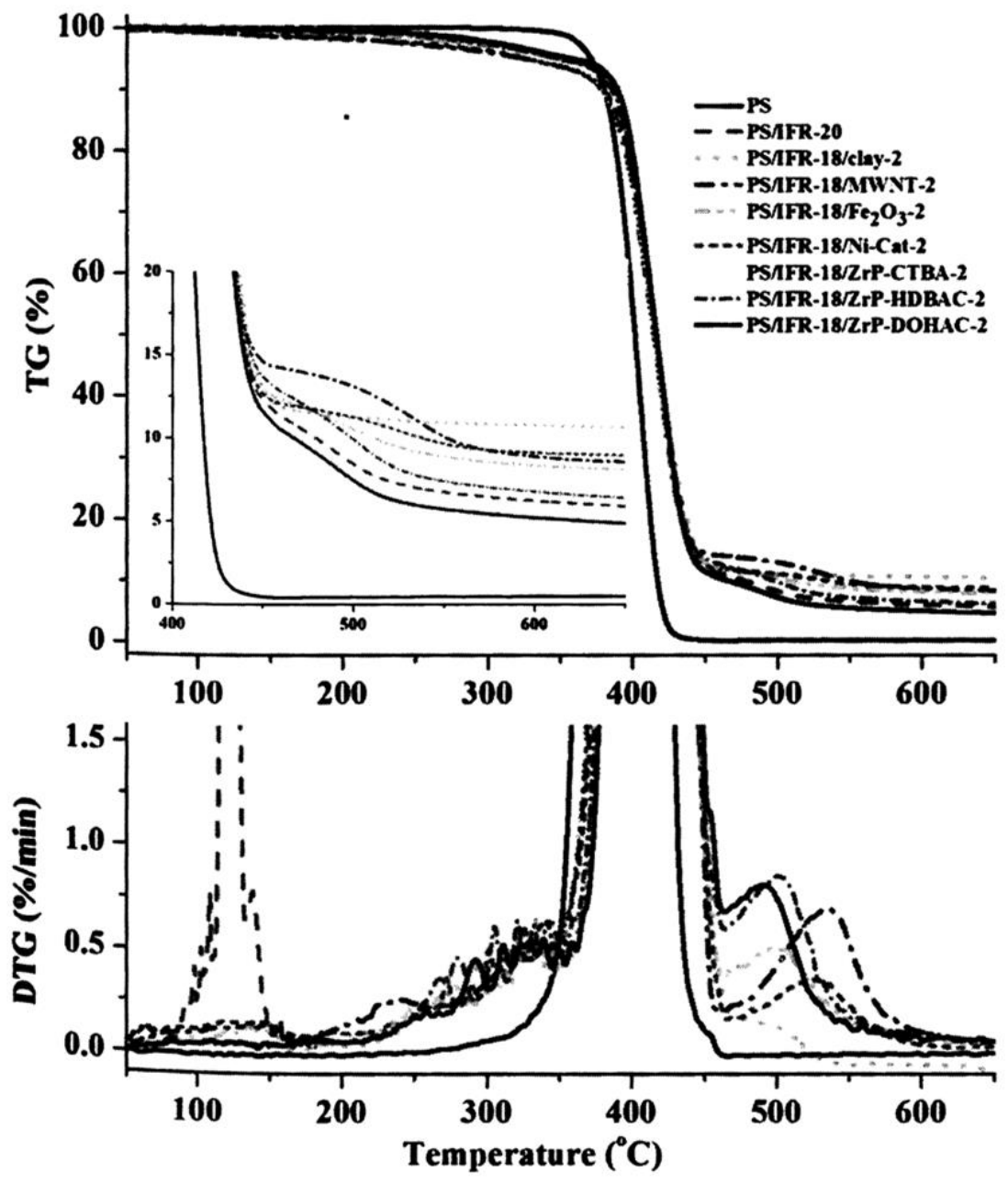

Polymer Degradation and Stability, Vol. 95, No. 12 (December 2010): pg. 2388-2395. DOI. This article is (c) Elsevier and permission has been granted for this version to appear in e-Publications@Marquette. Elsevier does not grant permission for this article to be further copied/distributed or hosted elsewhere without the express permission from Elsevier. 
NOT THE PUBLISHED VERSION; this is the author's final, peer-reviewed manuscript. The published version may be accessed by following the link in the citation at the bottom of the page.

Fig. 8.: Correlation between the char yield at $600^{\circ} \mathrm{C}$ in TGA and thereduction in peak HRR-Cone. (PHRR-Cone reduction: (PHRRComposites - PHRRPS)/PHRRPS)

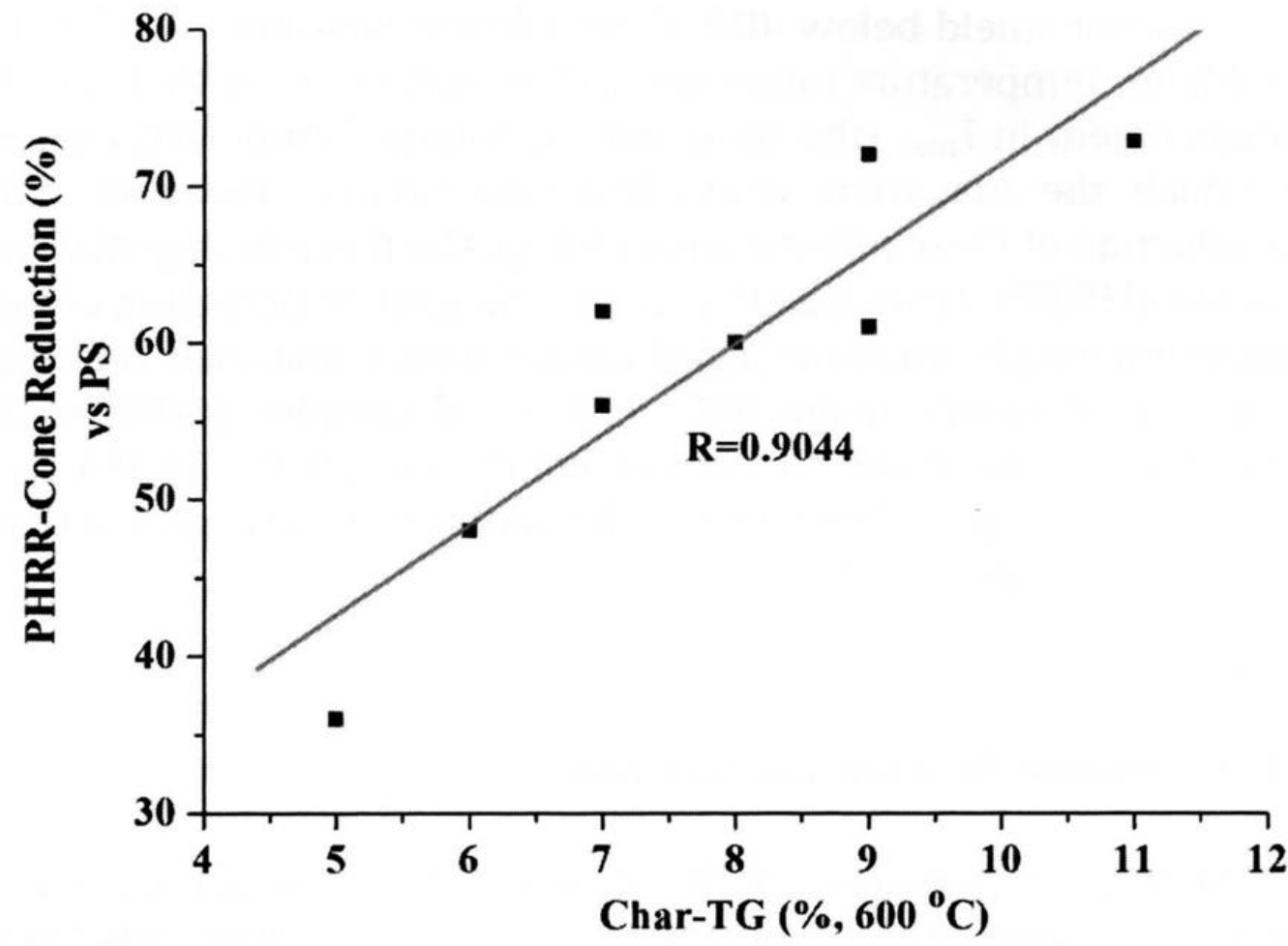

Polymer Degradation and Stability, Vol. 95, No. 12 (December 2010): pg. 2388-2395. DOI. This article is (C) Elsevier and permission has been granted for this version to appear in e-Publications@Marquette. Elsevier does not grant permission for this article to be further copied/distributed or hosted elsewhere without the express permission from Elsevier. 
NOT THE PUBLISHED VERSION; this is the author's final, peer-reviewed manuscript. The published version may be accessed by following the link in the citation at the bottom of the page.

Fig. 9.: Correlation between the $\triangle \mathrm{Char}$ in TGA and the reduction in peak HRR-Cone. $\left(\Delta\right.$ Char: $\left(\right.$ Char $\left.\left.600{ }^{\circ} \mathrm{C}-\mathrm{Char} 40^{\circ} \mathrm{C}\right) / \mathrm{Char}^{\circ} 50^{\circ} \mathrm{C}\right)$

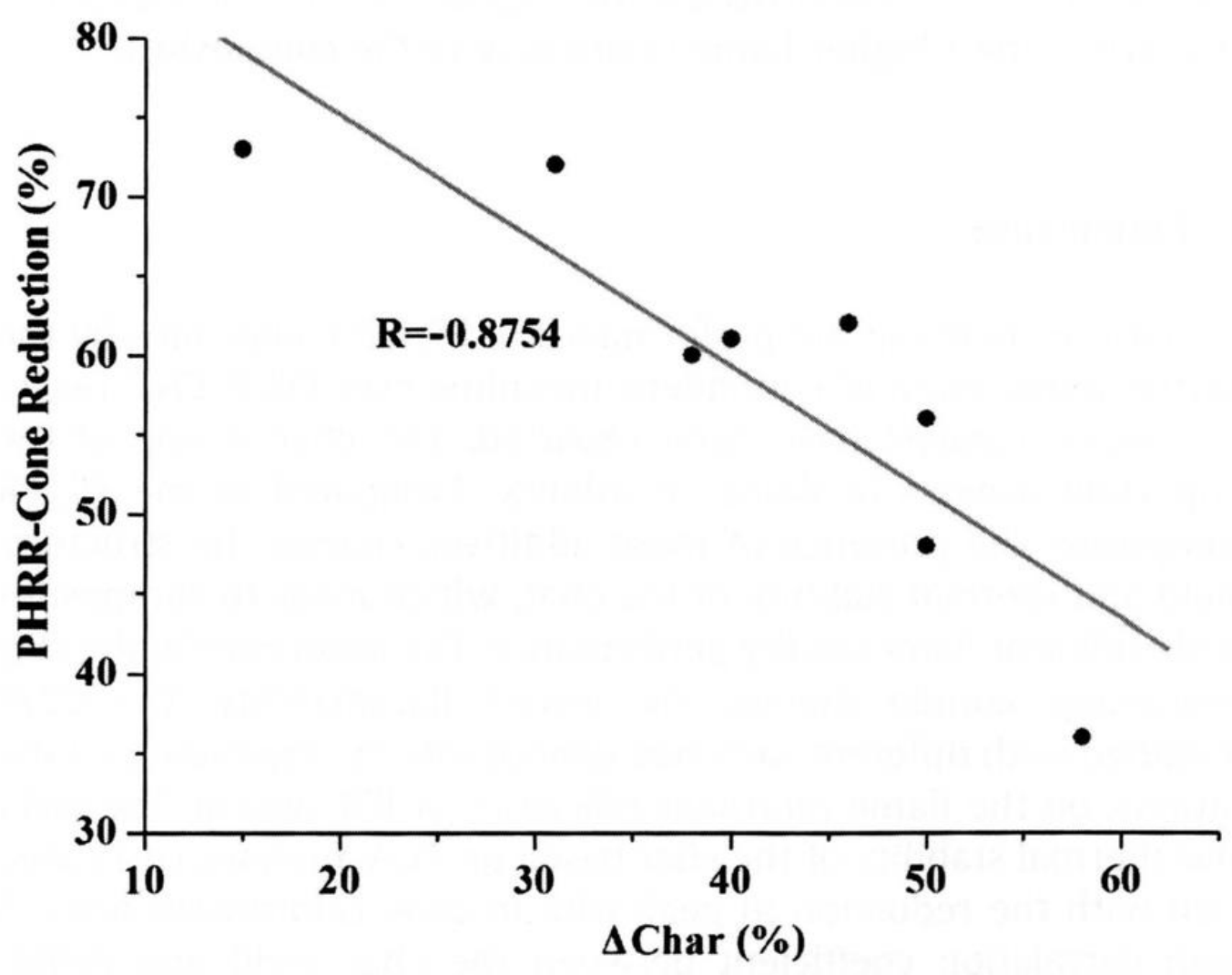

Polymer Degradation and Stability, Vol. 95, No. 12 (December 2010): pg. 2388-2395. DOI. This article is @ Elsevier and permission has been granted for this version to appear in e-Publications@Marquette. Elsevier does not grant permission for this article to be further copied/distributed or hosted elsewhere without the express permission from Elsevier. 